\title{
Pemilihan Supplier Berbasis Lingkungan: Studi Kasus pada PT. Warisan Eurindo
}

\author{
Bagus Haryo Ardi Cakra, dan Imam Baihaqi \\ Departemen Manajemen Bisnis, Institut Teknologi Sepuluh Nopember Surabaya (ITS) \\ e-mail: ibaihaqi@mb.its.ac.id
}

\begin{abstract}
Abstrak-Banyaknya isu lingkungan yang terjadi menyebabkan meningkatnya kesadaran masyarakat global akan pentingnya kelestarian lingkungan. Hal tersebut mengharuskan perusahaan untuk melakukan penerapan green supply chain management. Salah satu strategi pada green supply chain management adalah melakukan kerja sama dengan supplier yang ramah lingkungan atau green supplier. PT Warisan Eurindo merupakan salah satu perusahaan yang membutuhkan penerapan penilaian green supplier. Keperluan PT Warisan Eurindo didasarkan pada empat kondisi. Pertama, adalah kondisi dimana industri furnitur kayu di Indonesia yang menghadapi persaingan ketat di pasar global karena berkembangnya kesadaran konsumen dunia terhadap permasalahan lingkungan. Kedua, karena adanya regulasi pemerintah tentang FLEGT (Forest Law Enforcement Governance and Trade) yang mengatur tentang bagaimana perusahaan mendapatkan bahan baku kayu dengan cara yang ramah lingkungan. Ketiga, kondisi PT Warisan Eurindo yang saat ini hanya melayani pembuatan furnitur kayu yang berorientasi ekspor. Keempat, adanya kebijakan lingkungan yang ditekankan oleh manajemen perusahaan dalam melakukan pengadaan bahan baku. Penelitian ini menggunakan metode Analytical Hierarchy Process (AHP) untuk mendapatkan bobot dari setiap kriteria dan sub-kriteria green supplier sehingga dapat dilakukan penilaian alternatif supplier yang sesuai. Hasil penelitian menunjukkan bahwa terdapat tujuh kriteria dan 22 sub-kriteria yang diperlukan dalam penilaian green supplier, dengan hasil Perum Perhutani ditetapkan sebagai green supplier terbaik.
\end{abstract}

Kata Kunci-Analytical Hierarchy Process, Green Supply Chain Management, Pemilihan Supplier, Penilaian Green Supplier.

\section{PENDAHULUAN}

$\mathrm{S}$ EIRING bertumbuhnya masyarakat yang memiliki pemikiran dan kesadaran yang tinggi akan lingkungan, mereka secara tidak langsung ikut berperan penting dalam memberikan tantangan kepada para pelaku industri untuk memberikan jaminan kepada konsumen bahwa barang dan jasa yang di produksi aman bagi konsumen dan juga ramah lingkungan sehingga tidak berdampak pada rusaknya sistem lingkungan hidup. Isu lingkungan akibat dari kegiatan industri sudah dapat dirasakan oleh masyarakat khususnya di Indonesia. Contoh dari munculnya isu lingkungan adalah fakta bahwa 700 ribu hektare hutan di Jawa Timur mengalami kerusakan akibat adanya industri yang menggunakan lahan hutan serta yang menggunakan bahan baku kayu untuk kepentingan produksinya [1]. Isu lingkungan tersebut menunjukkan pentingnya perusahaan untuk memperhatikan lingkungan dalam menjalakan aktivitas industrinya, dimana perusahaan dapat membantu menurunkan isu lingkungan apabila melibatkan aspek lingkungan dalam menjalankan kegiatan usahanya [2]. Perusahaan juga harus memerhatikan aspek lingkungan karena adanya regulasi terkait lingkungan yang dikeluarkan oleh pemerintah tempat aktivitas industri berlangsung. Di berbagai negara, regulasi terkait lingkungan dikembangkan dan diterapkan dengan tujuan penghematan energi serta mengurangi tingkat pecemaran atau perusakan terhadap lingkungan [3]. Contoh regulasi lingkungan untuk pelaku industri yang dikeluarkan di Indonesia adalah UU No. 32 Tahun 2009 tentang Perlindungan dan Pengelolaan Lingkungan Hidup, serta UU No. 3 tahun 2014 tentang perindustrian termasuk industri hijau. Dengan adanya regulasi lingkungan tersebut, pemerintah Indonesia memiliki wewenang yang jelas untuk memberi sanksi kepada pelaku industri yang melakukan pelanggaran.

Aktivitas logistik dan supply chain turut berkontribusi secara signifikan terhadap lingkungan. Supply chain sendiri memiliki definisi berupa jaringan perusahaan-perusahaan yang secara bersama-sama bekerja untuk menciptakan dan mengahantarkan suatu produk ke tangan akhir [4]. Tantangan pada manajemen rantai pasok terdiri dari berbagai kompleksitas meliputi hubungan antara pemasok dengan perusahaan atau produsen, waktu, kualitas produk, permintaan pelanggan, serta biaya. Selain kompleksitas rantai pasok yang sudah disebutkan sebelumnya, terdapat tantangan lain bagi perusahaan, yaitu adanya isu lingkungan yang diakibatkan dari kegiatan operasional perusahaan. Green supply chain management (GSCM) atau manajemen rantai pasokan hijau adalah salah satu cara yang dapat digunakan untuk mengatasi kompleksitas pada manajemen rantai pasok maupun menghadapi tantangan terkait isu dan regulasi lingkungan yang harus dipatuhi oleh perusahaan. GSCM dapat dikatakan sebagai sebuah upaya untuk memasukkan isu-isu lingkungan dalam konteks manajemen rantai pasok. Aktivitas pembelian barang atau pengadaan merupakan salah satu fungsi utama pada supply chain management [5], yang juga berlaku pada green supply chain management [2]. Ketersediaan bahan baku akan terjamin dengan pemiilihan pemasok yang tepat, sehingga kestabilan produksi dapat terjaga. Terdapat permasalahan baru yang muncul ketika penentuan alternatif pemasok menjadi semakin kompleks karena adanya tuntutan konsep green supply chain management. Kriteria penting pemilihan pemasok pada aktivitas supply chain konvensional meliputi kualitas, harga, 


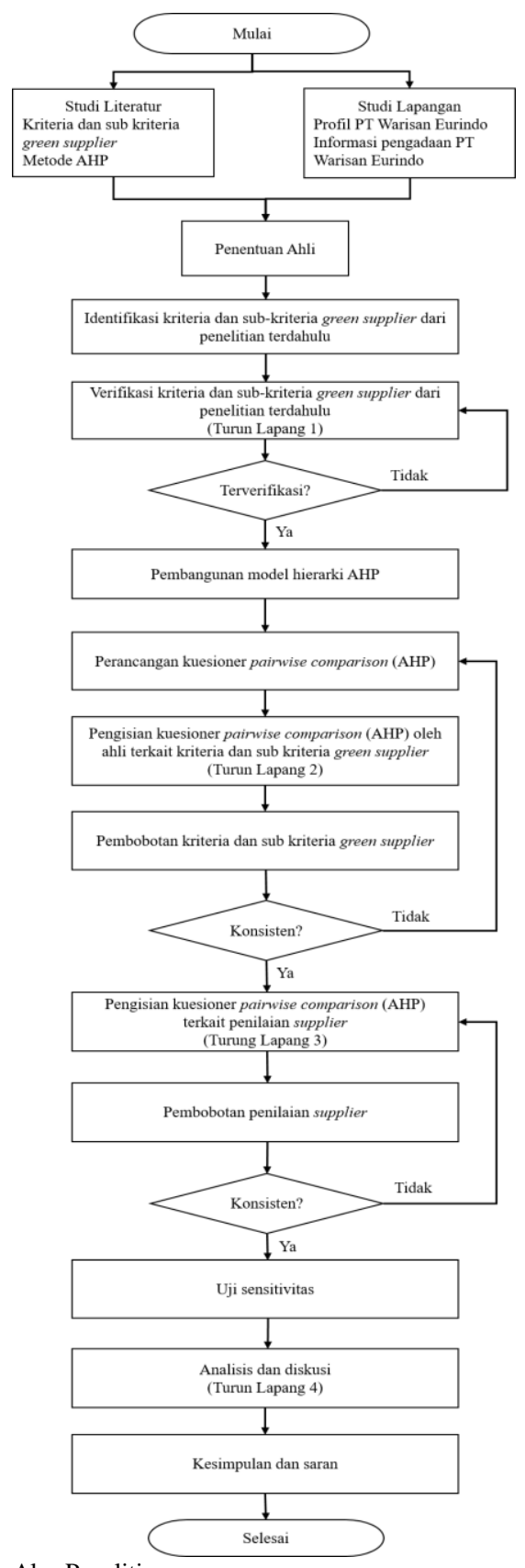

Gambar 1. Alur Penelitian

pengiriman, fleksibilitias, budaya, teknologi, inovasi, serta hubungan dengan pemasok [6]. Aspek tersebut sudah tidak lagi sesuai dengan tuntutan green supply chain management serta regulasi pemerintah seperti UU RI No. 05 Tahun 1984 pasal 3 mengenai perhatian terhadap lingkungan hidup. Oleh karena itu, dibuatlah konsep green supplier selection atau pemilihan pemasok hijau yang mempertimbangkan aspek lingkungan dalam melakukan pemilihan supplier.

PT Warisan Eurindo merupakan salah satu perusahaan yang membutuhkan penerapan penilaian green supplier. PT Warisan Eurindo merupakan perusahaan yang bergerak di bidang furnitur dengan bahan baku utama kayu. PT Warisan Eurindo memproduksi furnitur untuk hotel serta resort internasional. PT Warisan Eurindo memiliki fasilitas manufaktur di Jawa Timur dengan kantor pusat yang terletak di Bali, dan memperkerjakan kurang lebih 400 karyawan yang terdiri dari pengrajin, desainer, serta manajer proyek. Keperluan PT Warisan Eurindo didasarkan pada empat kondisi. Pertama, adalah kondisi dimana industri furnitur kayu di Indonesia yang menghadapi persaingan ketat di pasar global karena berkembangnya kesadaran konsumen dunia terhadap permasalahan lingkungan. Kedua, karena adanya regulasi pemerintah tentang FLEGT (Forest Law Enforcement Governance and Trade) yang mengatur tentang bagaimana perusahaan mendapatkan bahan baku kayu dengan cara yang ramah lingkungan. Ketiga, kondisi PT Warisan Eurindo yang saat ini hanya melayani pembuatan furnitur kayu yang berorientasi ekspor. Keempat, adanya kebijakan lingkungan yang ditekankan oleh manajemen perusahaan dalam melakukan pengadaan bahan baku. Berdasarkan kondisi PT Warisan Eurindo yang telah dijelaskan sebelumnya, diperlukan identifikasi kritera dan sub-kriteria green supplier yang sesuai bagi perusahaan serta penilaian supplier berbasis lingkungan sebagai strategi untuk menjawab tiga kepentingan PT Warisan Eurindo. Pertama, kepentingan untuk dapat memasuki pasar global khususnya Eropa, mengingat PT Warisan Eurindo adalah supplier resmi dari Four Seasons Hotel yang memiliki beberapa cabang hotel di benua Eropa. Kedua, kepentingan untuk mendukung regulasi pemerintah dalam mengurangi kerusakan lingkungan dengan menjalankan bisnis berdasarkan nilai lingkungan dan kebijakan KLHK. Hal ini juga berfungsi sebagai cara perusahaan untuk menghindari risiko terkena sanksi yang dikeluarkan pemerintah terhadap perusak lingkungan agar aktivitas perusahaan tidak terhambat. Ketiga, kepentingan untuk memiliki pertimbangan atau penilaian yang jelas dalam melakukan pengadaan bahan baku untuk meminimalkan risiko supplier yang bermasalah dengan kinerjanya, seperti pada aspek kualitas maupun pada aspek lingkungan. Hal ini dilakukan agar PT Warisan Eruindo dapat menjalankan kegiatan pengadaan bahan baku yang sesuai dengan prinsip perusahaan serta kegiatan produksi perusahaan tidak terhambat. Kerangka kerja untuk pemilihan green supplier dibutuhkan dalam rangka untuk memenuhi kepentingan PT Warisan Eurindo dalam kegiatan pengadaan bahan baku. Kerangka kerja akan berisi kriteria dan sub-kriteria green supplier yang diperlukan oleh PT Warisan Eurindo dalam menilai supplier. Kriteria dan sub-krtieria pemilihan green supplier diambil dari penelitian terdahulu dengan jenis perusahaan yang berbeda. Hal ini dikarenakan terbatasnya penelitian terdahulu terkait kriteria dan sub-kriteria green supplier pada perusahaan furnitur kayu.

\section{TINJAUAN PUSTAKA}

\section{A. Supply Chain Management}

Levi et.al (2000) mengartikan manajemen rantai pasok (supply chain management) sebagai suatu cara yang digunakan untuk melakukan pengintegrasian dari supplier, produsen, distributor, retailer, serta customer yang efektif dan efisien [7]. Dimana barang dapat diproduksi dalam kuantitas yang tepat, di waktu yang tepat, serta pada lokasi yang tepat untuk mencapai biaya yang minimum dari sistem secara keseluruhan dan tetap mencapai service level yang diharapkan [7]. 




Gambar 2. Kriteria final setelah verifikasi

\section{B. Green Supply Chain Management}

GSCM merupakan proses yang menggunakan masukan ramah lingkungan dan mengubah masukan tersebut menjadi keluaran yang dapat digunakan kembali pada akhir siklus hidupnya sehingga menciptakan rantai pasok yang berkelanjutan [8]. Berdasar pada penjelasan sebelumnya, dapat disimpulkan bahwa perbedaan antara supply chain management dengan green supply chain management adalah jika SCM pada praktiknya belum melibatkan aspek lingkungan sedangkan GSCM sudah mengintegrasikan aspek lingkungan pada rantai pasok. Kriteria final setelah verifikasi dapat dilihat pada Gambar 2.

\section{Pemilihan Supplier}

Menurut Pujawan (2017), supplier atau pemasok dapat diartikan sebagai pihak yang memiliki kepentingan terhadap keberhasilan manufacturer dalam menjalankan bisnisnya. Pemasok secara intensif mendukung keberhasilan proses operasi perusahaan [5]. Dukungan itu dapat dilihat dari penyediaan bahan baku yang dilakukan pemasok, dimana kualitas dari pemasok dapat dinilai dari produk jadi yang dihasilkan oleh perusahaan. Heizer dan Render (2010) berpendapat pemilihan pemasok mencakup proses menemukan pemasok yang potensial dan menentukan kemungkinan bahwa mereka akan menjadi pemasok yang terbaik [9].

\section{Pemilihan Green Supplier}

Penilaian supplier umum dengan green supplier memiliki perbedaan. Menurut Imeri et al. (2014) penilaian supplier dilakukan dengan menggabungkan antara indikator kuantitatif dan indikator kualitatif terkait supplier. Keuangan, kualitas dan pengiriman merupakan parameter yang paling umum digunakan dalam melakukan penilaian supplier [10]. Sedangkan penilaian green supplier berfokus pada faktor supplier yang umum seperti biaya rendah, kualitas yang baik, lead time pendek sembari memerhatikan isu lingkungan termasuk melakukan desain produk ramah lingkungan yang efisien dan pengelolaan limbah [11]. Peringkat kriteria green supplier dapat dilihat pada Gambar 3.

\section{E. Analytic Hierarchy Process}

Pemilihan supplier memiliki lebih dari satu kriteria atau subkriteria yang dipertimbangkan sehingga diperlukan metode Multi Criteria Decision Making (MCDM), yang salah satu metode dari MCDM adalah Analytic Hierarchy Process atau AHP. AHP merupakan metode pengukuran

menggunakan perbandingan berpasangan (pairwise comparison) dan bergantung pada penilaian para ahli untuk memperoleh skala prioritas [12]. AHP memungkinkan para pengambil keputusan melakukan evaluasi beberapa alternatif pilihan berdasarkan beberapa kriteria yang ada dan kemudian memilih pilihan yang optimal. Model dari AHP berupa hierarki linear sehingga prioritas dari atribut atau kriteria dapat dimodelkan.

\section{F. Posisi Penelitian}

Terdapat tiga topik utama yang menjadi acuan penelitian ini yaitu pemilihan supplier berbasis AHP, pemilihan green supplier, dan supply chain management pada industri furnitur kayu. Penelitian pemilihan supplier berbasis AHP diadopsi dari penelitian oleh Anggani et al. (2017). Penelitian pemilihan green supplier diadopsi dari Lee et al. (2009), Freeman dan Chen (2015), Guo et al. (2017), serta He dan Zhang (2018). Dan yang terakhir adalah topik supply chain management pada industri furnitur kayu yang diadopsi dari penelitian Robb et al. (2008), dan Michelsen et al. (2009). Peneliti akan mengkombinasikan penelitian-penelitian tersebut dalam merancang penelitian pemilihan supplier berbasis lingkungan menggunakan metode AHP di industri furnitur kayu.

\section{METODOLOGI PENELITIAN}

Penelitian ini merupakan penelitian studi kasus. Penelitian studi kasus merupakan pengujian empiris yang menyelidiki fenomena di dalam konteks kehidupan nyata, dengan tersedianya multisumber bukti yang dapat dimanfaatkan [13]. Penelitian ini menjelaskan tentang cara menentukan kriteria dan sub-kriteria green supplier hingga memilih green supplier berdasarkan metode AHP [4]. Wawancara dengan para ahli dilakukan untuk memilih dan memverifikasi kriteria dan subkriteria green supplier yang sesuai dengan kebutuhan perusahaan. Setelah kriteria dan sub-krtieria terverifikasi maka akan dikembangkan Model AHP sebagai dasar untuk membuat kuesioner perbandingan berpasangan yang akan diisi oleh para ahli. Pembobotan akan dilakukan setelah didapat data hasil dari kuesioner. Dengan menggunakan metode AHP, akan didapat peringkat bobot kriteria dan sub-kriteria green supplier serta 

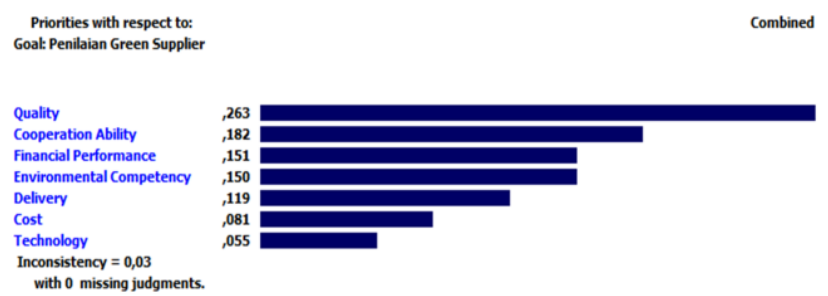

Gambar 3. Peringkat kriteria green supplier

Priorities with respect to: Goat: Penilaian Green Supplier

Quality Management System Product Qualification R
Defect Rate Reject Rate Inconsistency $=0,00258$



Gambar 4. Peringkat sub-kriteria dalam kriteria quality

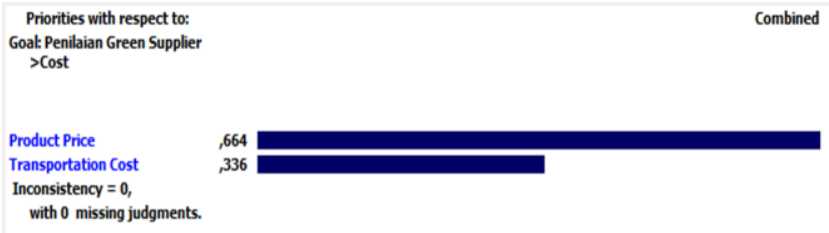

Gambar 5. Peringkat sub-kriteria dalam kriteria cost



penelitian ini.

\section{HASIL DAN PEMBAHASAN}

\section{A. Identifikasi Kriteria dan Sub-kriteria Green Supplier}

Hasil dari identifikasi dan verifikasi didapat tujuh kriteria dan 22 sub-kriteria green supplier. Verifikasi didapat dengan melakukan penyebarakan kuesioner kepada para ahli yang merupakan manajer pengadaan, manajer keuangan, serta manajer kualitas bahan baku PT Warisan Eurindo. Kriteria pada penelitian terdahulu menurut ahli memiliki kesesuaian dengan penilaian green supplier yang dibutuhkan oleh PT Warisan Eurindo. Kriteria green supplier tersebut meliputi quality, cost, delivery, technology, financial performance, cooperation ability, serta environmental competency.

Kriteria quality digunakan oleh PT Warisan Eurindo untuk melihat kualitas atau mutu dari produk yang ditawarkan oleh supplier. Selain itu, kriteria kualitas juga digunakan untuk melihat adanya perhatian yang besar dari supplier terhadap produk yang akan ditawarkan kepada PT Warisan Eurindo. Menurut PT Warisan Eurindo, produk dengan mutu atau kualitas yang baik mampu didapatkan ketika ada perhatian supplier terhadap aspek mutu terlibat dalam penciptaan produk. Kriteria cost juga diperhitungkan oleh PT Warisan Eurindo



Gambar 7. Peringkat sub-kriteria dalam kriteria technology

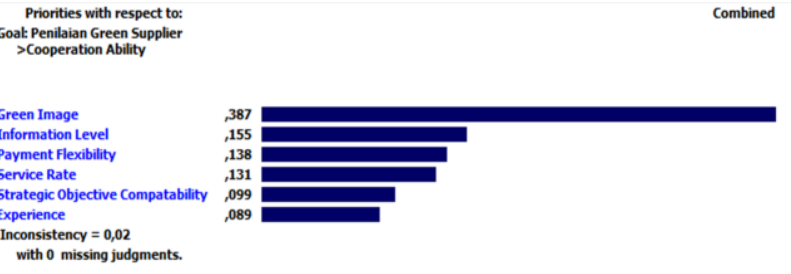

Gambar 8. Peringkat sub-kriteria dalam kriteria cooperation ability

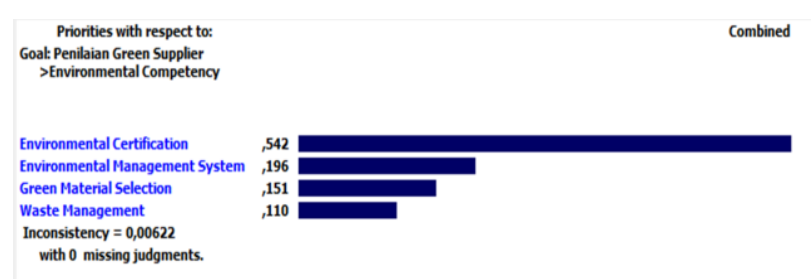

Gambar 9. Peringkat sub-kriteria dalam kriteria environmental competency

dalam memilih supplier, karena bekerja sama dengan supplier yang tepat dapat mengurangi biaya yang tidak perlu, seperti melakukan pembelian produk dengan kualitas yang sama namun biaya yang dikeluarkan lebih besar dari yang seharusnya. Kriteria cost juga diperlukan untuk melihat keseluruhan biaya yang akan dikeluarkan PT Warisan Eurindo dalam mendapatkan produk. Hal ini untuk menghindari adanya kesalahan dalam memperkirakan biaya, contohnya adalah jarak supplier dengan lokasi PT Warisan Eurindo. Untuk Delivery merupakan kriteria yang cukup penting karena mempengaruhi kegiatan produksi PT Warisan Eurindo. Cukup penting karena pengiriman produk dari supplier yang terlambat atau tidak sesuai dengan kesepakatan akan memberi dampak pada kinerja PT Warisan Eurindo. Kinerja PT Warisan Eurindo akan terganggu karena tidak dapat melakukan proses produksi dengan tepat waktu atau tidak sesuai dengan spesifikasi yang diinginkan. Selain itu kemajuan teknologi yang tidak dapat dihindari oleh perusahaan perlu dilibatkan dalam melakukan penilaian supplier. Penggunaan teknologi juga dapat mempengaruhi lingkungan sehingga perlu dilibatkan dalam penilaian green supplier. Teknologi yang dibutuhkan oleh PT Warisan Eurindo dari supplier adalah teknologi yang dapat menghasilkan produk yang mendukung kinerja produksi menjadi lebih efektif dan efisien dalam jangka panjang, baik saat ini maupun masa depan. Kriteria financial performance melambangkan kesehatan keuangan dari supplier. Supplier dengan financial performance yang baik akan memiliki pondasi yang kokoh untuk menjalankan tanggungjawabnya kepada pelanggan.

PT Warisan Eurindo memandang financial performance sebagai kriteria yang dapat memperlihatkan kestabilan supplier dalam menjalankan usahanya. Kriteria cooperation ability 
Tabel 1

Informasi supplier

\begin{tabular}{|c|c|c|c|}
\hline No & Nama & Lokasi & Status Usaha \\
\hline 1 & Perum Perhutani & Jakarta (kantor pusat) & $\begin{array}{l}\text { Badan usaha } \\
\text { milik negara }\end{array}$ \\
\hline 2 & PT Java Tectona & $\begin{array}{l}\text { Kalipuro, } \\
\text { Banyuwangi, Jawa } \\
\text { Timur }\end{array}$ & $\begin{array}{l}\text { Badan usaha } \\
\text { swasta }\end{array}$ \\
\hline 3 & UD Asri Jati & $\begin{array}{l}\text { Tahunan, Jepara, Jawa } \\
\text { Tengah }\end{array}$ & $\begin{array}{l}\text { Badan usaha } \\
\text { swasta }\end{array}$ \\
\hline 4 & UD Lestari & $\begin{array}{l}\text { Kalipuro, } \\
\text { Banyuwangi, Jawa } \\
\text { Timur }\end{array}$ & $\begin{array}{l}\text { Badan usaha } \\
\text { swasta }\end{array}$ \\
\hline
\end{tabular}



Gambar 10. Analisis sensitivitas keseluruhan

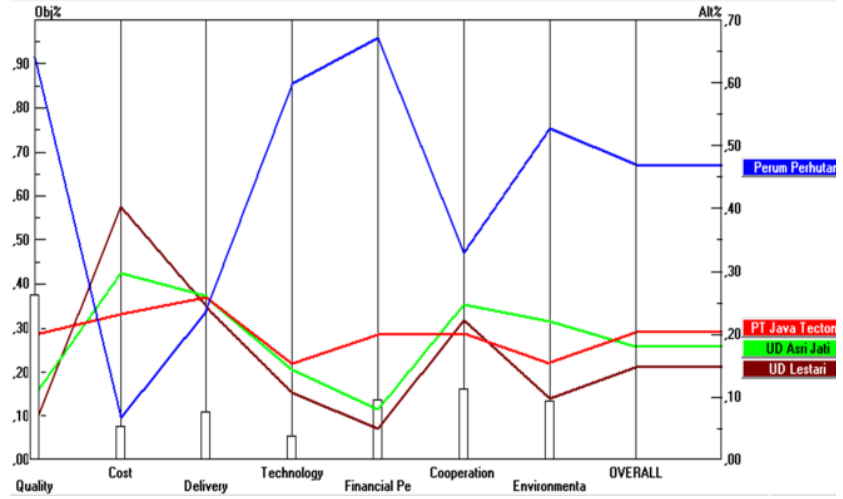

Gambar 11. Analisis sensitivitas pada kriteria quality

diperlukan untuk mengetahui kemampuan yang dimiliki supplier umum maupun green supplier dalam menjalankan kerjasama dengan perusahaan. Supplier dengan kemampuan kerjasama yang baik dibutuhkan PT Warisan Eurindo untuk mendukung kinerja produksi. Hal ini dikarenakan supplier dengan kemampuan kerjasama yang baik dapat melakukan kegiatan pengadaan sesuai dengan kebutuhan PT Warisan Eurindo. Selain itu, kemampuan kerjasama yang baik dapat mengurangi risiko terjadinya pengadaan yang bermasalah akibat supplier yang tidak memiliki kemampuan kerjasama yang mumpuni, atau karena informasi dalam rantai pasok yang terbatas.

Adanya keterlibatan lingkungan merupakan kriteria pembeda antara penilaian supplier umum dengan green supplier. Kriteria environmental competency digunakan pada penilaian supplier PT Warisan Eurindo untuk mengetahui kepedulian supplier terhadap lingkungan.Informasi Supplier dapat dilihat pada Tabel 1.
Tabel 2.

Pembobotan supplier PT Warisan Eurindo

\begin{tabular}{|c|c|c|c|c|c|}
\hline $\begin{array}{l}\text { Kriteria/Sub- } \\
\text { kriteria }\end{array}$ & Bobot & $\begin{array}{l}\text { Perum } \\
\text { Perhutani }\end{array}$ & $\begin{array}{l}\text { PT Java } \\
\text { Tectona }\end{array}$ & $\begin{array}{l}\text { UD } \\
\text { Asri Jati }\end{array}$ & $\begin{array}{l}\text { UD } \\
\text { Lestari }\end{array}$ \\
\hline $\begin{array}{l}\text { Quality } \\
\text { Product }\end{array}$ & $\begin{array}{l}0,263 \\
0,081\end{array}$ & 0,685 & 0,164 & 0,093 & 0,058 \\
\hline $\begin{array}{l}\text { Qualification } \\
\text { Rate }\end{array}$ & & & & & \\
\hline Reject Rate & 0,047 & 0,685 & 0,164 & 0,093 & 0,058 \\
\hline Defect Rate & 0,049 & 0,685 & 0,164 & 0,093 & 0,058 \\
\hline $\begin{array}{l}\text { Quality } \\
\text { Management } \\
\text { System }\end{array}$ & 0,086 & 0,565 & 0,262 & 0,118 & 0,055 \\
\hline Cost & 0,081 & & & & \\
\hline Product Price & 0,054 & 0,073 & 0,170 & 0,284 & 0,473 \\
\hline $\begin{array}{l}\text { Transportation } \\
\text { Cost }\end{array}$ & 0,027 & 0,063 & 0,313 & 0,313 & 0,313 \\
\hline Delivery & 0,119 & & & & \\
\hline $\begin{array}{l}\text { On Time Delvery } \\
\text { Rate }\end{array}$ & 0,032 & 0,100 & 0,300 & 0,300 & 0,300 \\
\hline $\begin{array}{l}\text { Order Fulfilment } \\
\text { Rate }\end{array}$ & 0,049 & 0,704 & 0,122 & 0,122 & 0,052 \\
\hline Lead Time & 0,039 & 0,100 & 0,300 & 0,300 & 0,300 \\
\hline Technology & 0,055 & & & & \\
\hline $\begin{array}{l}\text { Capability of } \\
\text { Green RnD }\end{array}$ & 0,010 & 0,750 & 0,083 & 0,083 & 0,083 \\
\hline $\begin{array}{l}\text { Cleaner } \\
\text { Production } \\
\text { Technology }\end{array}$ & 0,045 & 0,571 & 0,165 & 0,153 & 0,111 \\
\hline $\begin{array}{l}\text { Financial } \\
\text { Perfomance }\end{array}$ & 0,151 & & & & \\
\hline Quick Ratio & 0,151 & 0,670 & 0,200 & 0,080 & 0,050 \\
\hline $\begin{array}{l}\text { Cooperation } \\
\text { Ability }\end{array}$ & 0,182 & & & & \\
\hline $\begin{array}{l}\text { Payment } \\
\text { Flexibility }\end{array}$ & 0,025 & 0,042 & 0,550 & 0,269 & 0,138 \\
\hline $\begin{array}{l}\text { Informantion } \\
\text { Level }\end{array}$ & 0,028 & 0,041 & 0,252 & 0,252 & 0,455 \\
\hline Service Rate & 0,024 & 0,060 & 0,162 & 0,288 & 0,491 \\
\hline Green Image & 0,070 & 0,565 & 0,107 & 0,230 & 0,098 \\
\hline $\begin{array}{l}\text { Strategic } \\
\text { Objective }\end{array}$ & 0,018 & 0,572 & 0,109 & 0,209 & 0,109 \\
\hline $\begin{array}{l}\text { Compatability } \\
\text { Experience }\end{array}$ & 0,016 & 0,576 & 0,118 & 0,243 & 0,062 \\
\hline $\begin{array}{l}\text { Environmental } \\
\text { Compentency }\end{array}$ & 0,150 & & & & \\
\hline $\begin{array}{l}\text { Waste } \\
\text { Management }\end{array}$ & 0,016 & 0,0532 & 0,185 & 0,185 & 0,097 \\
\hline $\begin{array}{l}\text { Environmental } \\
\text { Management } \\
\text { System }\end{array}$ & 0,029 & 0,518 & 0,099 & 0,284 & 0,099 \\
\hline $\begin{array}{l}\text { Green Material } \\
\text { Selection }\end{array}$ & 0,023 & 0,518 & 0,099 & 0,284 & 0,099 \\
\hline $\begin{array}{l}\text { Environmental } \\
\text { Certification }\end{array}$ & 0,081 & 0,532 & 0,185 & 0,185 & 0,097 \\
\hline Bobot Total & & 0,440 & 0,204 & 0,193 & 0,163 \\
\hline
\end{tabular}

\section{B. Pembobotan Kriteria dan Sub-kriteria Green Supplier}

Bobot masin g-masing kriteria didapat dari perbandingan berpasangan yang mengikuti metodologi AHP. Perbandingan berpasangan didapat dari kuesioner yang diisi oleh para ahli yang sama pada tahap verifikasi. Hasil kuesioner kemudian diolah menggunakan Expert Choice ${ }^{T M}$.

Nilai Inkonsistensi sebesar 0,0260 yang menandakan data tersebut konsisten karena nilai inkonsistensi masih di bawah 0,1 . Kriteria dengan peringkat bobot tertinggi pertama didapat oleh quality $(0,263)$, diikuti oleh cooperation ability $(0,0182)$, financial performance $(0,151)$, environmental competency $(0,150)$, delivery $(0,119)$, cost $(0,081)$, dan technology $(0,055)$. 


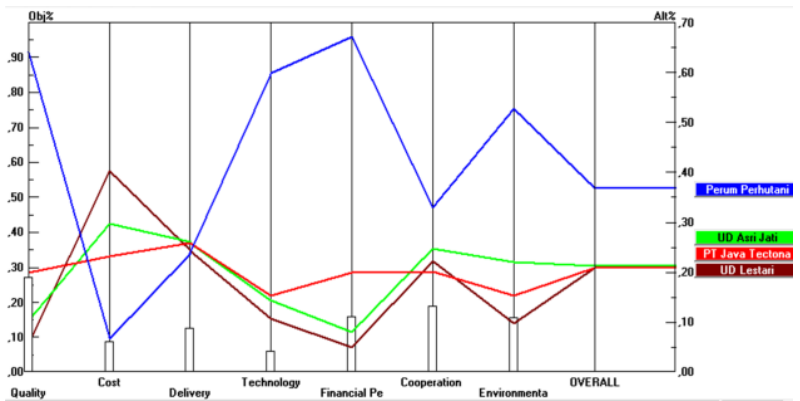

Gambar 12. Analisis sensitivitas pada kriteria cost


Kriteria quality memilki 4 sub-kriteria dengan quality management system memiliki peringkat pertama dengan bobot 0,325. Lalu peringkat kedua dimiliki sub-kriteria product qualification rate dengan bobot 0,309. Pada peringkat ketiga dan keempat secara berurutan dimiliki oleh sub-kriteria defect rate dengan bobot 0,187 dan reject rate dengan bobot 0,179 .

Kriteria cost hanya memiliki 2 sub-kriteria yang dapat dilihat pada gambar 5. Dimana sub-kriteria product price memiliki peringkat pertama dengan bobot 0,664 . Lalu peringkat kedua dimiliki sub-kriteria transportation cost dengan bobot 0,336 .

Kriteria delivery memiliki 3 sub-kriteria dimana tingkat kepentingan sub-kriteria tersebut dapat dilihat pada gambar 6 . Sub-kriteria order fulfilment rate memiliki peringkat pertama dengan bobot 0,410 . Lalu peringkat kedua dimiliki sub-kriteria lead time dengan bobot 0,324. Peringkat terakhir dimiliki olehsub-kriteria on time delivery rate dengan bobot 0,265.Peringkat sub-kriteria dalam kriteria quality dapat dilihat pada Gambar 4.

Sama seperti kriteria cost, kriteria technology hanya memiliki 2 sub-kriteria yang dapat dilihat pada gambar 7. Subkriteria cleaner production technology memiliki peringkat pertama dengan bobot 0,819 dan sub-kriteria capability of green $R n D$ pada peringkat kedua dengan bobot 0,181 . Sedangkan kriteria financial performance hanya memilki satu


sub-kriteria yaitu quick ratio, sehingga sub-kriteria tersebut tidak bisa dilakukan pairwise comparison dan memiliki bobot lokal mutlak sebesar 1 .

Gambar 8 menunjukkan peringkat enam sub-kriteria pada kriteria cooperation ability. Dimana sub-kriteria green image memiliki peringkat pertama dengan bobot 0,387 . Peringkat kedua dimiliki sub-kriteria information level dengan bobot 0,155 . Pada peringkat ketiga dan keempat secara berurutan dimiliki oleh sub-kriteria payment flexibility dengan bobot 0,138 dan service rate dengan bobot 0,131 . Lalu pada peringkat kelima dan keenam secara berurutan dimiliki oleh sub-kriteria strategic objective compatability dengan bobot 0,099 dan subkriteria experience dengan bobot 0,089 .

Kriteria environmental competency memiliki 4 sub-kriteria yang dapat dilihat pada gambar 9. Peringkat pertama subkriteria pada kriteria environmental competency dimiliki oleh environmental certification dengan bobot 0,542. Lalu disusul oleh sub-kriteria environmental management system pada peringkat kedua dengan bobot 0,196. Dan peringkat ketiga dan keempat secara berurutan dimiliki oleh sub-kriteria green material selection dengan bobot 0,151 dan waste management dengan bobot 0,110 . 


\section{Pembobotan Supplier}

Setelah bobot masing-masing kriteria dan sub-kriteria green supplier berhasil ditentukan, langkah selanjutnya adalah melakukan pembobotan supplier berdasarkan kriteria dan subkriteria tersebut. Berikut merupakan data masing-masing supplier yang akan dilakukan penilaian.

Supplier akan dinilai terhadap masing-masing sub-kriteria dengan menggunakan perbandingan berpasangan mengikuti metode AHP, yang didapat dari hasil kuesioner yang diisi oleh ahli yang sama pada tahap verifikasi, ditambah dengan direktur pabrik PT Warisan Eurindo. Berbeda dengan langkah sebelumnya, ahli akan mengisi kuesioner perbandingan berpasangan secara bersama dengan menggunakan metode focus group discussion. Pengolahan data perbandingan berpasangan akan tetap menggunakan software Expert Choice $^{T M}$.

Dilihat dari nilai keseluruhan, dapat disimpulkan bahwa Perum Perhutani akan dipilih daripada PT Java Tectona, UD Asri Jati, dan UD Lestari. Nilai keseluruhan Perum Perhutani, PT Java Tectona, UD Asri Jati, dan UD Lestari secara berurutan adalah 0,440; 0,204; 0,193; dan 0,163. Nilai inkonsistensi untuk pembobotan ini adalah 0,02 yang masih di bawah 0,1 sehingga data dapat disimpulkan konsisten.

\section{Analisis Sensitivitas}

Analisis sensitivitas dilakukan dengan mengubah bobot dari kriteria yang digunakan. Bobot akan diubah sebesar $\pm 10 \%$ ke atas (upward change) atau ke bawah (downward change) untuk menganalisis apakah peringkat dari supplier terpilih akan berubah atau tidak berubah (robust). Analisis sensitivitas keseluruhan dapat dilihat pada Gambar 10.

1) Analisis sensitivitas pada kriteria quality

Peringkat dari supplier tetap sama walaupun dilakukan perubahan bobot pada kriteria quality secara upward change maupun downward change. Analisis sensitivitas pada kriteria quality dapat dilihat pada Gambar 11 .

2) Analisis sensitivitas pada kriteria cost

Peringkat dari supplier berubah jika dilakukan perubahan bobot pada kriteria cost secara upward change. Perubahan tersebut terjadi pada PT Java Tectona dan UD Asri Jati, dimana UD Asri Jati menjadi peringkat kedua dan PT Java Tectona turun ke peringkat ketiga. Perubahan secara downward change pada bobot kriteria biaya tidak memberikan perubahan pada peringkat supplier. Analisis sensitivitas pada kriteria cost dapat dilihat pada Gambar 12 .

3) Analisis sensitivitas pada kriteria delivery

Peringkat dari supplier tetap sama walaupun dilakukan perubahan bobot pada kriteria delivery secara upward change maupun downward change.Analisis sensitivitas pada kriteria delivery dapat dilihat pada Gambar 13.

4) Analisis senstivitas pada kriteria technology

Peringkat dari supplier tetap sama walaupun dilakukan perubahan bobot pada kriteria technology secara upward change maupun downward change.Analisa sensitivitas pada kriteria technology dapat dilihat pada Gambar 14.

5) Analisis sensitivitas pada kriteria financial performance

Peringkat dari supplier tetap sama walaupun dilakukan perubahan bobot pada kriteria financial performance secara upward change maupun downward change dapat dilihat pada Gambar 15.

6) Analisis sensitivitas pada kriteria cooperation ability

Peringkat dari supplier tetap sama walaupun dilakukan perubahan bobot pada kriteria cooperation ability secara upward change maupun downward change dapat dilihat pada Gambar 16.

\section{7) Analisis sensitivitas pada kriteria environmental} competency

Peringkat dari supplier tetap sama walaupun dilakukan perubahan bobot pada kriteria environmental competency secara upward change maupun downward change dapat dilihat pada Gambar 17.

\section{KESIMPULAN DAN SARAN}

\section{A. Kesimpulan}

Berdasarkan hasil dan pembahasan yang didapat pada penelitian terdapat beberapa kesimpulan sebagai berikut.

1) Bagi PT Warisan Eurindo sebagai perusahaan yang bergerak dalam bidang industri furnitur, terdapat tujuh kriteria dan 22 sub-kriteria pemilihan green supplier. Kriteria tersebut meliputi quality, cost, delivery, technology, financial performance, cooperation ability, dan environmental competency.

2) Peringkat kriteria penilaian green supplier berdasarkan pembobotan dengan metode AHP secara berurutan adalah quality (0,263), cooperation ability (0,0182), financial performance $(0,151)$, environmental competency $(0,150)$, delivery $(0,119)$, cost $(0,081)$, dan technology $(0,055)$.

3) Hasil dari pembobotan supplier PT Warisan Eurindo, diputuskan Perum Perhutani sebagai supplier berbasis lingkungan terbaik dengan dengan bobot total sebesar 0,440 Pembobotan supplier PT Warisan Eurindo dapat dilihat pada Tabel 2.

4) Analisis sensitivitas dilakukan untuk menunjukkan pengaruh perubahan bobot kriteria dalam peringkat pemilihan supplier. Analisis sensitivitas pada masingmasing kriteria menunjukkan hasil yang tetap terhadap peringkat supplier kecuali pada kriteria cost, dimana peringkat UD Asri Jati naik menjadi peringkat kedua dan PT Java Tectona turun menjadi peringkat ketiga.

\section{B. Keterbatasan Penelitian}

Penelitian ini memiliki keterbatasan pada kondisi saat melakukan wawancara verifikasi dan pengisian kuesioner. Kondisi setiap ahli belum tentu pada kondisi ideal dan dapat berbeda antar ahli, sehingga hasil dari verifikasi maupun kuesioner belum tentu bersifat ideal.

\section{Saran}

Berikut adalah saran yang dapat diimplementasikan oleh PT Warisan Eurindo dan juga untuk penelitian selanjutnya: 1) Kriteria dan sub-kriteria green supplier beserta bobotnya dapat dijadikan acuan untuk melakukan penilaian dalam proses pemilihan supplier serta evaluasi kinerja supplier, dengan pembaharuan ulang kriteria apabila kriteria dianggap sudah 
tidak sesuai dengan kebutuhan perusahaan, 2) Melakukan komunikasi dan edukasi terhadap supplier, dimana informasi mengenai peringkat kriteria dan sub-kriteria green supplier dapat mengedukasi supplier untuk mengetahui kriteria apa yang menjadi prioritas perusahaan dalam melakukan pemilihan supplier, 3) Penelitian yang dilakukan hanya terbatas pada pemilihan supplier, penelitian selanjutnya dapat melakukan perancangan kerangka kerja penilaian green supplier untuk melakukan evaluasi supplier dan program supplier development, dengan melibatkan pihak luar yang merupakan ahli pihak green supplier.

\section{DAFTAR PUSTAKA}

[1] "Melihat Kejahatan Dalam Tata Kelola Hutan di Jawa Timur || Adil dan Lestari." http://walhijatim.or.id/2018/06/melihat-kejahatan-dalam-tatakelola-hutan-di-jawa-timur/ (accessed Jul. 29, 2020).

[2] M. Li and C. Wu, "Green supplier selection based on improved intuitionistic fuzzy TOPSIS model.," Metall. Min. Ind., no. 6, 2015.

[3] K. Shahzad Baig and M. Yousaf, "Coal fired power plants: emission problems and controlling techniques," J Earth Sci Clim Chang., vol. 8, no. 404, p. 2, 2017.

[4] I. N. Pujawan and E. Mahendrawathi, "Supply Chain Management,
Surabaya." Guna Widya Press, 2005.

[5] I. N. Pujawan and E. Mahendrawathi, "Supply Chain Management." Penerbit Andi, Yogyakarta, 2017.

[6] S. H. Amin and G. Zhang, "An integrated model for closed-loop supply chain configuration and supplier selection: Multi-objective approach," Expert Syst. Appl., vol. 39, no. 8, pp. 6782-6791, 2012.

[7] F. Chen, Z. Drezner, J. K. Ryan, and D. Simchi-Levi, "Quantifying the bullwhip effect in a simple supply chain: The impact of forecasting, lead times, and information," Manage. Sci., vol. 46, no. 3, pp. 436-443, 2000.

[8] S. V Walton, R. B. Handfield, and S. A. Melnyk, "The green supply chain: integrating suppliers into environmental management processes," Int. J. Purch. Mater. Manag., vol. 34, no. 1, pp. 2-11, 1998.

[9] J. Heizer and B. Render, "Manajemen Operasi Buku 1 Edisi 9," Jakarta: Salemba, vol. 4, 2009.

[10] K. Govindan, S. Rajendran, J. Sarkis, and P. Murugesan, "Multi criteria decision making approaches for green supplier evaluation and selection: a literature review," J. Clean. Prod., vol. 98, pp. 66-83, Jul. 2015, doi: 10.1016/J.JCLEPRO.2013.06.046.

[11] R. Villanueva-Ponce, L. Avelar-Sosa, A. Alvarado-Iniesta, and V. G. Cruz-Sánchez, "The green supplier selection as a key element in a supply chain: A review of cases studies," Dyna, vol. 82, no. 194, pp. 36-45, 2015.

[12] T. L. Saaty and M. Sodenkamp, "The analytic hierarchy and analytic network measurement processes: the measurement of intangibles," in Handbook of multicriteria analysis, Springer, 2010, pp. 91-166.

[13] R. K. Yin, Applications of case study research. sage, 2011. 